\title{
Extended Elemental lodine Adsorption by AgZ under Prototypical Vessel Off-Gas Conditions
}

\section{Nuclear Technology}

Research and Development

Approved for public release. Distribution is unlimited.

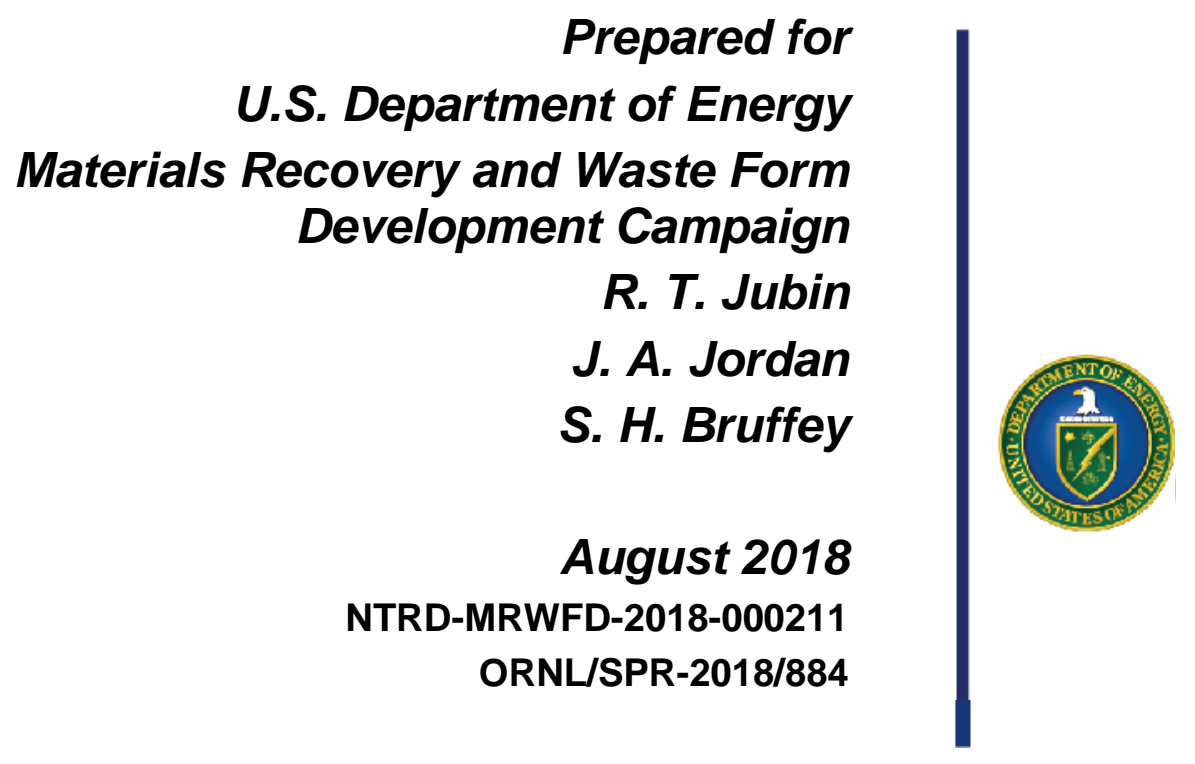





\section{DISCLAIMER}

This information was prepared as an account of work sponsored by an agency of the U.S. Government. Neither the U.S. Government nor any agency thereof, nor any of their employees, makes any warranty, expressed or implied, or assumes any legal liability or responsibility for the accuracy, completeness, or usefulness, of any information, apparatus, product, or process disclosed, or represents that its use would not infringe privately owned rights. References herein to any specific commercial product, process, or service by trade name, trade mark, manufacturer, or otherwise, does not necessarily constitute or imply its endorsement, recommendation, or favoring by the U.S. Government or any agency thereof. The views and opinions of authors expressed herein do not necessarily state or reflect those of the U.S. Government or any agency thereof. 



\section{SUMMARY}

US regulations will require the removal of ${ }^{129}$ I from the off-gas streams of any used nuclear fuel (UNF) reprocessing plant prior to discharge of the off-gas to the environment. Multiple off-gas streams within a UNF reprocessing plant combine prior to environmental release, and each of these streams contains some amount of iodine. For an aqueous UNF reprocessing plant, these streams include the dissolver off-gas (DOG), the cell off-gas (COG), the vessel off-gas (VOG), the waste off-gas (WOG), and the shear off-gas (SOG). To achieve regulatory compliance, treatment of multiple off-gas streams within the plant must be performed. Of these remaining streams, the VOG is expected to be one of the major contributors to the balance of the residual iodine releases. The VOG will most likely contain iodine at parts-per-billion $\left(\mathrm{ppb}^{*}\right)$ concentrations.

Preliminary studies were completed on the adsorption of $\mathrm{I}_{2}$ onto hydrogen-reduced silver mordenite $\left(\mathrm{Ag}^{0} \mathrm{Z}\right)$ from prototypical VOG streams. The previous tests were of relatively short duration (3-4 months) and loaded the sorbent to far less than its expected saturation loading. As a result, little to no information could be extracted regarding the length of the mass transfer zone or the long-term concurrent sorbent aging and loading behavior. The test reported here is the first part of a series of long-duration tests designed to identify the saturation loading of the sorbent under VOG conditions and, as a part of this, to determine the length of the mass transfer zone.

This test represents the longest extended VOG test conducted to date by this program. This test ran 38 weeks and achieved iodine loadings of $\sim 40 \mathrm{mg} \mathrm{I} / \mathrm{g}$ sorbent. The iodine mass transfer zone penetrated at least $10.5 \mathrm{~cm}$ into the sorbent beds. There was no indication of sorbent saturation. The mass balance for iodine closed within $2 \%$, which is within the expected combined uncertainty.

While this test did not achieve saturation of any portion of the test beds, the data does provide significant information that can be used to extrapolate a potential maximum length of the mass transfer zone under VOG conditions. Under the conditions used in this test, the mass transfer zone could be on the order of $21 \mathrm{~cm}$.

This test also provides the basis for the design of the next series of extended VOG tests. Future tests to examine the validity of the extrapolation to a saturated VOG sorbent bed should be designed to run up to $\sim 4.9$ years, assuming a $50 \mathrm{ppb} \mathrm{I}_{2}$ feed gas, and have a bed length greater than $32 \mathrm{~cm}$.

Future efforts regarding the adsorption of iodine from prototypical VOG streams by silver-based sorbents will attempt to extend the test duration to (1) determine if the slope of the iodine loading front remains constant; (2) determine the saturation concentration reflecting aging in situ; and (3) compare the extended loading behavior for organic iodides. Additionally, the adsorption of different iodine species, such as $\mathrm{C}_{12} \mathrm{H}_{25} \mathrm{I}$, will be studied. Other variables that merit examination are the gas velocity of the test and the dependence of the observed results on the inlet iodine concentration.

\footnotetext{
* Throughout this report, ppb or ppm concentrations will be used on a molar basis.
} 


\section{CONTENTS}

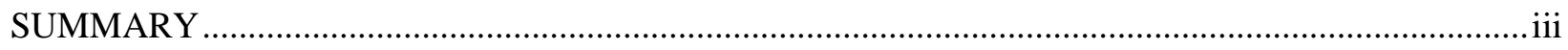

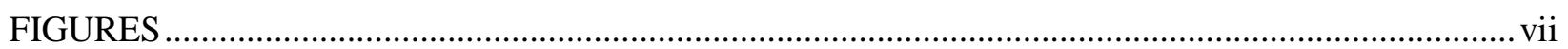

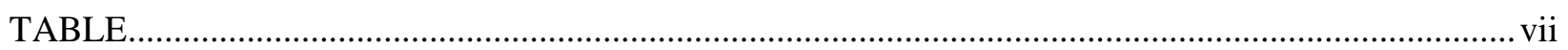

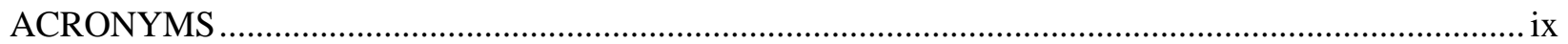

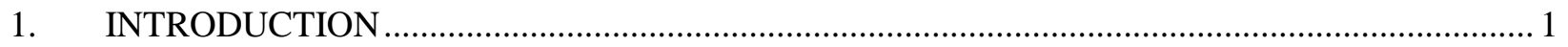

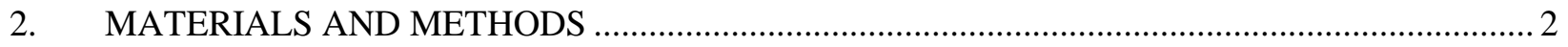

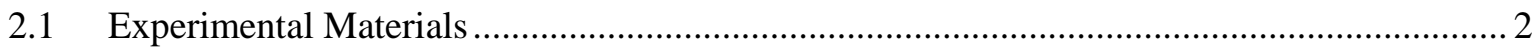

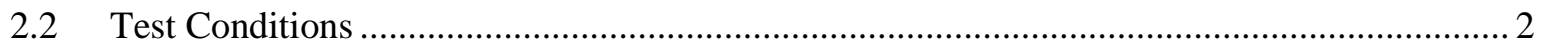

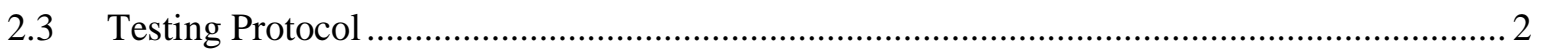

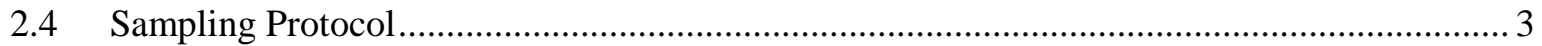

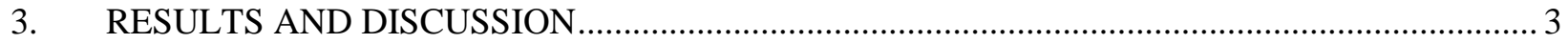

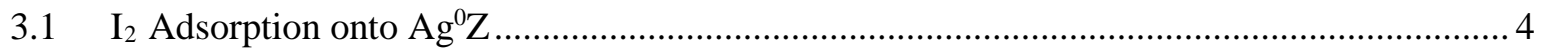

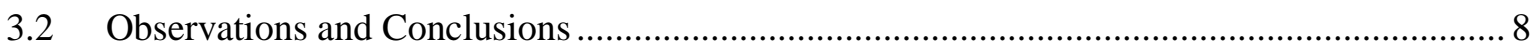

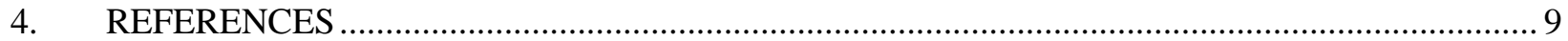




\section{FIGURES}

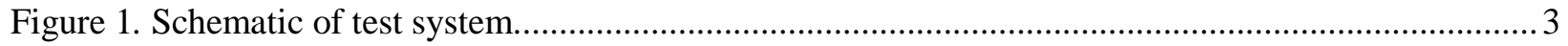

Figure 2. Penetration of $I_{2}$ into Bed 1 of the test system. .................................................................... 5

Figure 3. Linear regression fit for the mass transfer zone for the extended $I_{2}$ sorption onto $\mathrm{Ag}^{0} \mathrm{Z} \ldots \ldots \ldots \ldots . . .6$

Figure 4. Estimated penetration of $\mathrm{I}_{2}$ into an $\mathrm{Ag}^{0} \mathrm{Z}$ deep bed at breakthrough based on linear regression fit of loading shown in Figure 3 with a saturation loading of $90 \mathrm{mg} \mathrm{I} / \mathrm{g}$ sorbent.

Figure 5. Estimated penetration of $\mathrm{I}_{2}$ into an $\mathrm{Ag}^{0} \mathrm{Z}$ deep bed at breakthrough based on linear regression fit of loading shown in Figure 3 with a saturation loading of 45 mg I $/ 2$ sorbent. 8

\section{TABLE}

Table 1. Data obtained for Bed 1 of extended $I_{2}$ adsorption test \#1 
Extended Elemental lodine Adsorption by AgZ under Prototypical Vessel Off-Gas Conditions 


\section{ACRONYMS}

$\begin{array}{ll}\mathrm{AgZ} & \text { Silver mordenite } \\ \mathrm{Ag}^{0} \mathrm{Z} & \text { Reduced silver mordenite } \\ \mathrm{COG} & \text { Cell off-gas } \\ \text { DF } & \text { Decontamination factor } \\ \text { DOG } & \text { Dissolver off-gas } \\ \text { NAA } & \text { Neutron activation analysis } \\ \text { SOG } & \text { Shear off-gas } \\ \text { UNF } & \text { Used nuclear fuel } \\ \text { VOG } & \text { Vessel off-gas } \\ \text { WOG } & \text { Waste off-gas }\end{array}$




\section{EXTENDED ELEMENTAL IODINE ADSORPTION BY AgZ UNDER PROTOTYPICAL VESSEL OFF-GAS CONDITIONS}

\section{INTRODUCTION}

US regulations will require the removal of ${ }^{129}$ I from the off-gas streams of any used nuclear fuel (UNF) reprocessing plant prior to discharge of the off-gas to the environment. The release of volatile radioactive iodine is governed by three regulations in the United States (40 CFR 61, 40 CFR 190, and 10 CFR 20). These regulations govern both total release limits for iodine and the potential combined dose from the four volatile radionuclides of most concern for reprocessing $\left({ }^{3} \mathrm{H},{ }^{14} \mathrm{C},{ }^{85} \mathrm{Kr}\right.$, and $\left.{ }^{129} \mathrm{I}\right)$. The required plant decontamination factor (DF) for iodine will vary based on fuel burnup, cooling time, and other factors but is very likely to be $>1000$ and could be as high as 8000 (Jubin et al. 2012).

Multiple off-gas streams are generated within a UNF reprocessing plant, and the total from all of these streams must be considered when assessing the environmental release since each contains some amount of iodine. For an aqueous UNF reprocessing plant, these streams include the dissolver off-gas (DOG), the cell off-gas (COG), the vessel off-gas (VOG), the waste off-gas (WOG), and the shear off-gas (SOG). While 95-98\% of the total iodine inventory of UNF is expected to be released to the DOG, even complete removal of iodine from the DOG without treatment of other streams would result in an overall plant DF of $<100$ (Jubin et al. 2013). Thus, to achieve regulatory compliance, treatment of multiple off-gas streams within the plant must be performed.

Of these remaining streams, the VOG is expected to be one of the major contributors to the balance of the residual iodine releases. The VOG will most likely contain iodine at parts-per-billion (ppb*) concentrations. Vessel off-gas refers to the gas venting from all chemical process tanks and equipment in the primary (non-waste) process line downstream of dissolver operations, including the solvent extraction operations that occur during aqueous UNF reprocessing. Volatile components and their degradation products present in the solvent extraction vessels can transfer to these gas streams and/or react with the iodine present in liquid or gas phases. The VOG will most likely contain iodine at ppb concentrations. The VOG is also the stream most likely to contain organic iodides, which have been considered more difficult to remove (or more penetrating) than $\mathrm{I}_{2}$ when using with traditional sorbents (Bruffey et al. 2015a).

Silver-exchanged mordenite (AgZ) has been considered a promising iodine sorbent for use in UNF reprocessing plants, but recent efforts have identified silver-functionalized silica-aerogel (AgAerogel) as an alternative iodine sorbent. In testing under simulated DOG stream conditions, AgAerogel demonstrates a resistance to degradation from $\mathrm{NO}_{x}$ gases present within the plant, has high iodine loadings by weight, and is easily converted to a condensed waste form through hot isostatic pressing (Bruffey et al. 2015b; Matyas et al. 2016). However, the mechanism for iodine adsorption and immobilization by AgAerogel is not yet understood, and it is not currently available in an engineered form with a large particle size and resistance to mechanical and thermal degradation.

Several years ago, Oak Ridge National Laboratory initiated an effort to evaluate both hydrogen-reduced AgZ ( $\left.\mathrm{Ag}^{0} \mathrm{Z}\right)$ and AgAerogel under simulated VOG conditions. Initial tests were performed to evaluate the adsorption of elemental and organic iodine (Jubin et al. 2015; Bruffey et al. 2016). These tests were typically 3-4 months in duration because at the low iodine concentrations in the prototypical VOG stream, considerable time was required to even begin to achieve significant iodine loading on the sorbent materials as compared to loading with prototypic DOG streams. These efforts were continued in 2017 and

\footnotetext{
* Throughout this report, ppb or ppm concentrations will be used on a molar basis.
} 
characterized the adsorption of $7 \mathrm{ppb} \mathrm{I}_{2}$ by $\mathrm{Ag}^{0} \mathrm{Z}$, $40 \mathrm{ppb}$ methyl iodide $\left(\mathrm{CH}_{3} \mathrm{I}\right)$ by $\mathrm{Ag}^{0} \mathrm{Z}$, and $40 \mathrm{ppb}$ $\mathrm{CH}_{3} \mathrm{I}$ by AgAerogel (Jubin, et al. 2017).

The previous tests were of relatively short duration (3-4 months) and loaded the sorbent to far less than its expected saturation loading. As a result, little to no information could be extracted regarding the length of the mass transfer zone or the long-term concurrent sorbent aging and loading behavior. The test reported here is the first part of a series of long-duration tests designed to identify the saturation loading of the sorbent under VOG conditions and, as a part of this, to determine the length of the mass transfer zone.

\section{MATERIALS AND METHODS}

\subsection{Experimental Materials}

Silver mordenite was obtained from Molecular Products in an engineered pelletized form (Ionex-Type Ag 900 E16). It contains $9.4 \mathrm{wt} \%$ silver and has a $0.16 \mathrm{~cm}$ pellet diameter. Prior to use in testing, the sorbent material was reduced by exposure to a $4 \% \mathrm{H}_{2}$ blend in argon at $270^{\circ} \mathrm{C}$ for 10 days. After reduction, the material was stored under argon to limit oxidation by air. Details of this procedure are provided by Anderson et al. (2012).

Due to the corrosive nature of iodine, especially in the presence of water, the materials of construction for the system were carefully selected to minimize iodine loss to system components and piping. The sorbent beds were contained within glass columns (internal diameter $=2.73 \mathrm{~cm}$ ) and separated by glass frits. The test bed system consisted of three separate deep beds in series, as shown in Figure 1. The glass connections between the beds were built to allow a slipstream to be pulled between beds. These were used to qualitatively verify that flow was passing through the bed.

The humid air and iodine supply streams were piped through separate lines of 316 stainless steel tubing. The two streams were blended together in a glass tee directly prior to introduction into the sorbent bed. Each glass column was filled with $~ 90$ g of mordenite, resulting in a bed depth of $17.35 \mathrm{~cm}$. each.

\subsection{Test Conditions}

For this $\mathrm{I}_{2}$ adsorption test, the iodine stream was generated by a KinTek Flexstream Gas Standards Generator. Testing lasted from 31 May 2017 to 23 February 2018, for a total of 268 days online. During the first 127 days of testing, three permeation tubes were used in the KinTek with a combined emission rate of $1866 \mathrm{ng} / \mathrm{min}$. During the second phase of the test (141 days), a single permeation tube with an emission rate of $2097 \mathrm{ng} / \mathrm{min}$ was used. The concentrated iodine stream from the KinTek was combined with a humidified air stream such that the resulting feed gas stream provided a face velocity of $\sim 10 \mathrm{~m} / \mathrm{min}$ (based on the empty column diameter), a $0^{\circ} \mathrm{C}$ dew point, and elemental iodine concentration of $\sim 50 \mathrm{ppb}$.

The sorbent beds were held at $150^{\circ} \mathrm{C}$, and the gas stream was preheated to $150^{\circ} \mathrm{C}$ prior to contact with the sorbent beds.

\subsection{Testing Protocol}

The test system was left in the oven at operating temperature for the duration of the test period. Throughout the course of the test, minor feed gas outages occurred as a result of system maintenance operations (such as refilling of the humidity generator). During the course of this test, no sampling of the individual beds was conducted to avoid disturbing the iodine loading profile. 

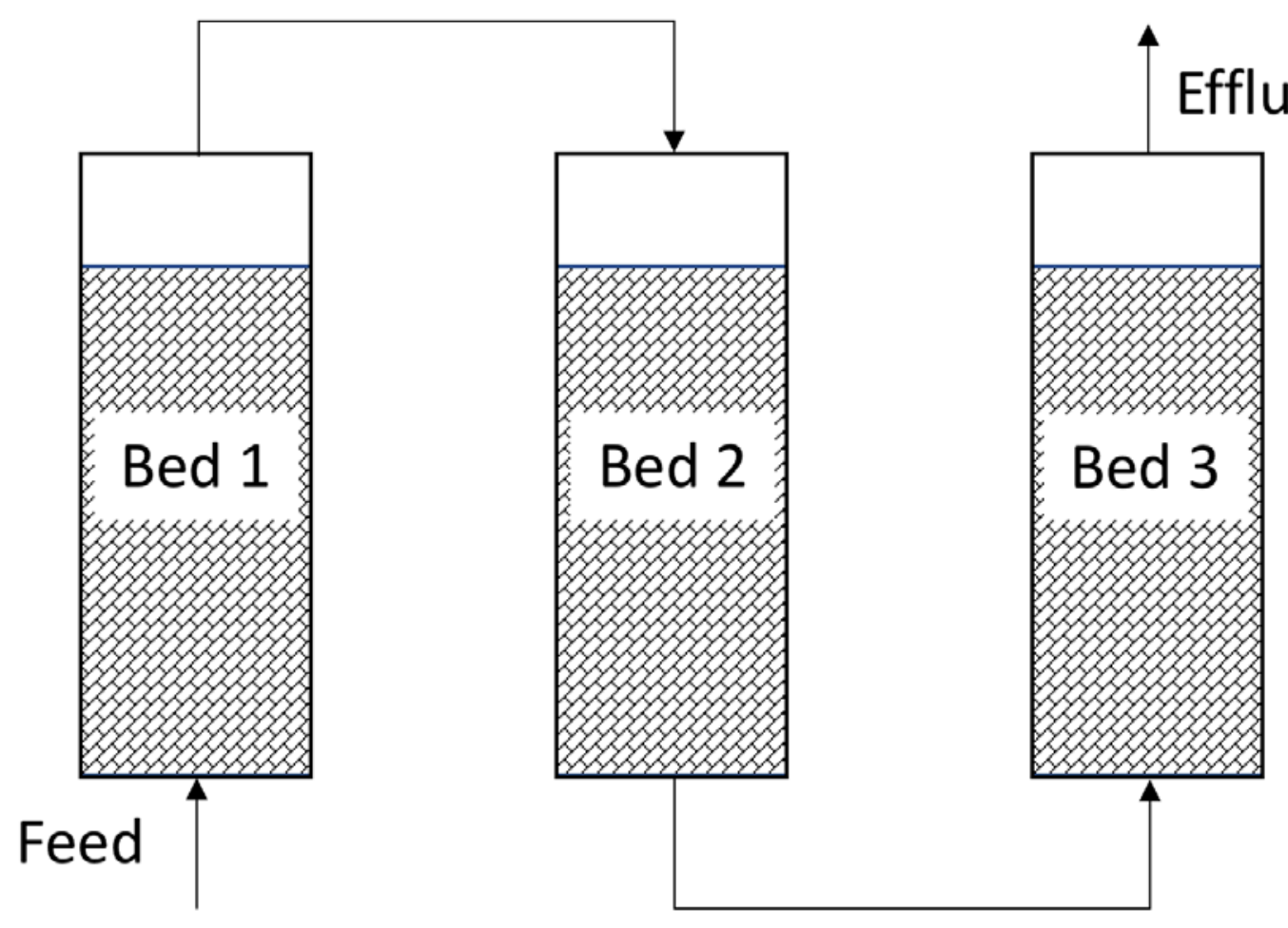

Figure 1. Schematic of test system.

\subsection{Sampling Protocol}

At the end of the test period, the individual beds were sampled by vacuuming and collecting discrete portions beginning at the top of each bed. The sections were nominally $1 \mathrm{~cm}$. in length in the first bed and $1.25 \mathrm{~cm}$ in the second and third beds. The segments recovered from the first bed had an average weight of $5.75 \mathrm{~g}$. Each of these bed segments was individually mixed by hand in glass containers. A small subsample of roughly $0.2 \mathrm{~g}$ was taken from each of the segments from the first bed and sent for neutron activation analysis (NAA) at ORNL's High Flux Isotope Reactor to determine iodine content.

\section{RESULTS AND DISCUSSION}

The $I_{2}$ adsorption test was completed successfully. The $I_{2}$ adsorption test concluded after 38 weeks. The amount of iodine found on the sorbent by NAA, along with other associated key data for each sorbent sample, is shown in Table 1. As iodine was not expected to penetrate into the second and third sorbent beds, only selected segments from the first bed were analyzed. The first 10 segments of the first sorbent bed displayed measurable iodine loading. 
Table 1. Data obtained for Bed 1 of extended $\mathrm{I}_{2}$ adsorption test \#1

\begin{tabular}{|c|c|c|c|c|c|}
\hline Sample & $\begin{array}{l}\text { Sample } \\
\text { Weight }\end{array}$ & $\begin{array}{l}\text { Segment } \\
\text { Length }\end{array}$ & $\begin{array}{l}\text { Cummulative } \\
\text { Length }\end{array}$ & $\begin{array}{l}\text { Iodine } \\
\text { Collected }\end{array}$ & $\begin{array}{l}\text { NAA } \\
\text { Uncertainty }\end{array}$ \\
\hline & (g) & $(\mathrm{cm})$ & $(\mathrm{cm})$ & $\begin{array}{l}\text { (mg I/g } \\
\text { sorbent) }\end{array}$ & $\begin{array}{l}\text { ( } \pm \text { mg I/g } \\
\text { sorbent) }\end{array}$ \\
\hline Section 1 & 6.2587 & 1.21 & 1.21 & 38.8399 & 0.5684 \\
\hline Section 2 & 8.0743 & 1.56 & 2.76 & 32.2192 & 0.4680 \\
\hline Section 3 & 6.3494 & 0.65 & 3.41 & 21.3214 & 0.3204 \\
\hline Section 4 & 6.6753 & 1.29 & 4.69 & 15.7153 & 0.2372 \\
\hline Section 5 & 5.361 & 1.03 & 5.73 & 11.7351 & 0.1831 \\
\hline Section 6 & 5.3931 & 1.04 & 6.77 & 4.6500 & 0.0763 \\
\hline Section 7 & 6.5487 & 1.26 & 8.03 & 2.5852 & 0.0459 \\
\hline Section 8 & 6.4116 & 1.24 & 9.27 & 0.6815 & 0.0172 \\
\hline Section 9 & 4.6104 & 0.89 & 10.12 & 0.1649 & 0.0100 \\
\hline Section 10 & 4.0461 & 0.78 & 10.93 & 0.0075 & 0.0071 \\
\hline Section 11 & 6.6901 & 1.29 & 12.22 & MDA $^{*}$ & \\
\hline Section 12 & 5.7895 & 1.12 & 13.34 & $\mathrm{MDA}^{*}$ & \\
\hline Section 13 & 4.4243 & 0.85 & 14.19 & $\mathrm{MDA}^{*}$ & \\
\hline Section 14 & 5.8134 & 1.12 & 15.31 & $\mathrm{MDA}^{*}$ & \\
\hline Section 29 & 6.5295 & 1.26 & 16.57 & $\mathrm{MDA}^{*}$ & \\
\hline Section 30 & 5.4074 & 1.04 & 17.61 & $\mathrm{MDA}^{*}$ & \\
\hline Section 31 & 3.626 & 0.70 & 18.31 & MDA $^{*}$ & \\
\hline
\end{tabular}

\section{$3.1 \quad \mathrm{I}_{2}$ Adsorption onto $\mathrm{Ag}^{0} \mathrm{Z}$}

As noted above, the three beds were removed in sections/layers by vacuum. The sections were each homogenized, and then, in the case of Bed 1, a small portion was removed for analysis and considered to be the average loading for that section. The results from the NAA are presented in Table 1 and graphically shown in Figure 2. The black bars in Figure 2 represent the length of sorbent bed that was removed and homogenized prior to analysis and are plotted to show the average loading of that section. The dotted line is plotted through the midpoint of the section length. The section length was based upon the density of the as-received material, $0.886 \mathrm{~g} / \mathrm{cm}^{3}$, and the weight of each removed section. The density of the material may be altered during testing as the material contacts a humid air stream. 
The vertical lines through the midpoint of each segment bar in Figure 2 represent the error band for that data point. This error band is composed of two parts; the first part is the uncertainty associated with the NAA analysis (this is shown in Table 1), and the second part is an estimate of the variable of a single $0.2 \mathrm{~g}$ sub-sample from the larger $5-8 \mathrm{~g}$ sample. This variability was previously determined to be $12 \%-$ $27 \%$ for subsamples that represented $2 \%-3 \%$ of a large deep bed and $\sim 10 \%$ for subsamples that represent significantly larger fractions of thin beds (Jubin et al. 2017). For this estimation of sampling variance, the value of $10 \%$ was selected.

As a check of the system, the total amount of iodine recovered from the sorbent bed was compared to the intended delivery amount based on the permeation rates. The amount of iodine recovered on the beds was approximately $102 \%$ of the amount that was expected to be delivered. This is within the combined error band.

As shown in Figure 2, the iodine mass transfer zone penetrated approximately $10.5 \mathrm{~cm}$ into Bed 1 . For purposes of this test, the maximum extent of penetration was defined as the midpoint of the first section containing $<0.1 \mathrm{mg} \mathrm{I/g}$ sorbent. There was also no indication of saturation loading at the bed inlet. The iodine loadings on the first and second bed segments of Bed 1 (each $\sim 1 \mathrm{~cm}$ in depth) were $38.8 \mathrm{mg} \mathrm{I}_{2} / \mathrm{g}$ sorbent and $32.2 \mathrm{mg} \mathrm{I}_{2} / \mathrm{g}$ sorbent, respectively. It was also noted that over the first 6-6.5 $\mathrm{cm}$ the iodine loading appeared to be linear or nearly linear as a function of bed depth.

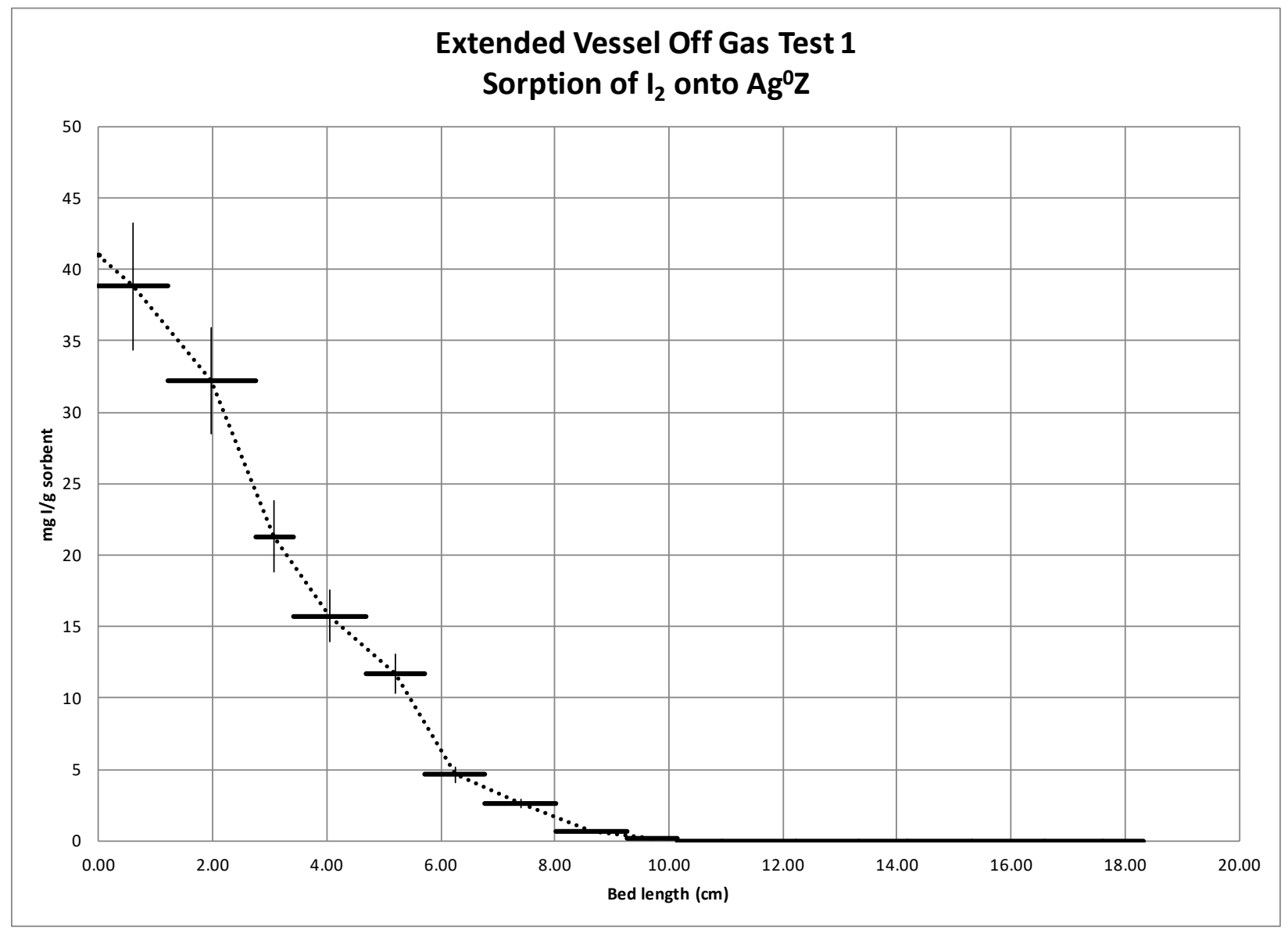

Figure 2. Penetration of $I_{2}$ into Bed 1 of the test system. 
Figure 3 shows this same data with a linear regression fit for the initial bed segments. The resulting equation is

$$
y=m x+b,
$$

where

$$
\begin{aligned}
& y=\text { mg I / gm sorbent, } \\
& x=\text { penetration depth }(\mathrm{cm}), \\
& m=-6.122 \mathrm{mg} \mathrm{I} / \text { gm sorbent } / \mathrm{cm} \text {, and } \\
& b=42.361 \mathrm{mg} \mathrm{I} / \text { gm sorbent. }
\end{aligned}
$$

The coefficient of correlation $\left(\mathrm{R}^{2}\right)$ is 0.983 .

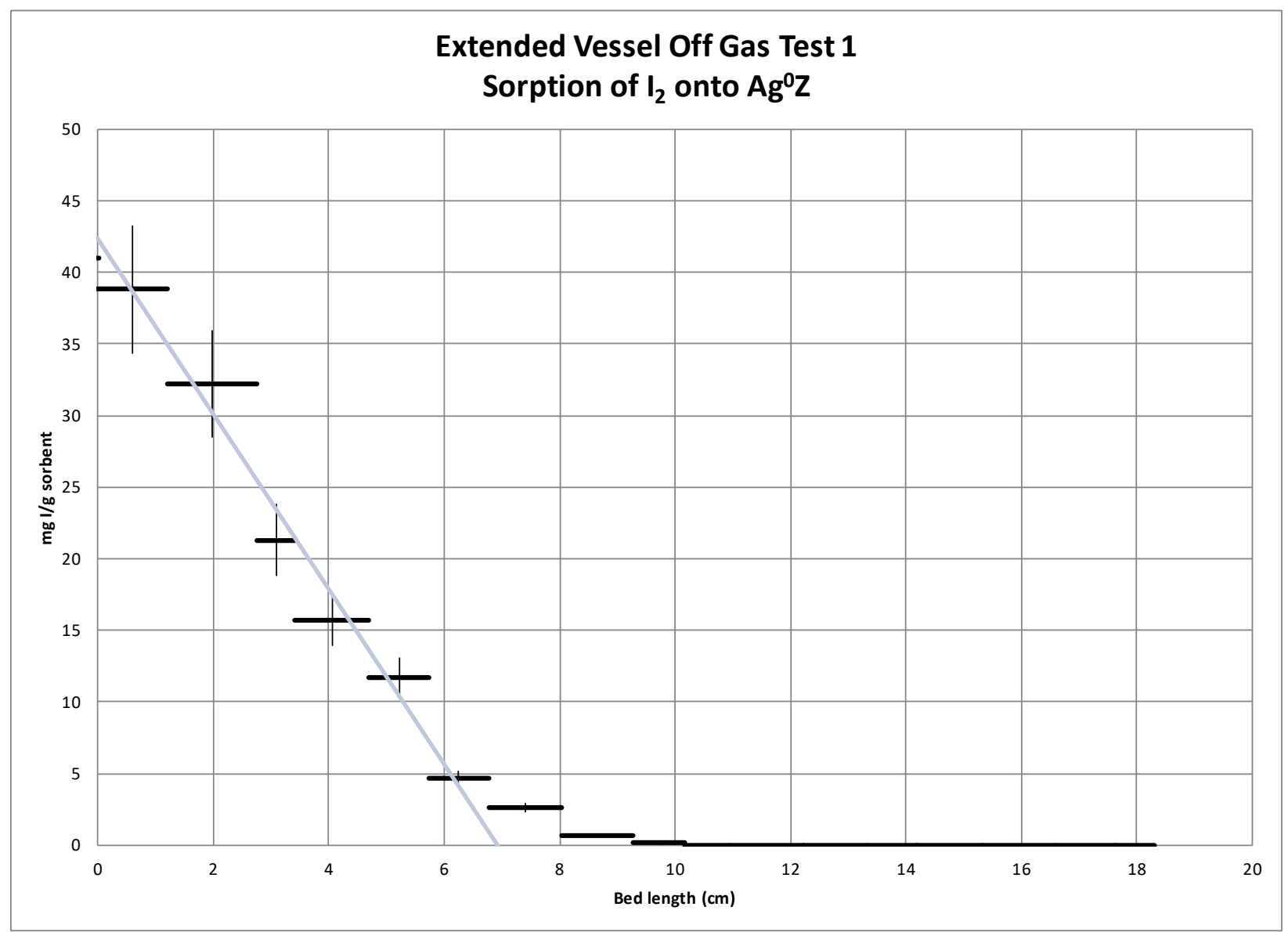

Figure 3. Linear regression fit for the mass transfer zone for the extended $\mathrm{I}_{2}$ sorption onto $\mathrm{Ag}^{0} \mathrm{Z}$.

It is clear from Figure 2 that the inlet had not yet reached saturation, and as a result the length of the mass transfer zone could not be determined from this test data. However, assuming that the linear relationship shown in Figure 3 continues with the same slope as the bed loading continues, an estimate of the time to reach a specified level of saturation can be made. Figure 4 represents such an estimate. In this case, a saturation loading goal of $90 \mathrm{mg} \mathrm{I} / \mathrm{g}$ sorbent is specified, corresponding to a silver utilization of $80 \%$. This is believed to be a very conservative value considering the aging of the sorbent that would occur during the course of the test based on previous studies by Jubin (2011) that examined the effect of 
extended aging at $150^{\circ} \mathrm{C}$ with both dry and humid streams for periods up to 6 months prior to iodine loading. These tests showed a $40 \%$ capacity loss for a 6 month exposure to dry streams and $60 \%$ loss for a 4 month exposure to a humid air stream. Symmetry is also assumed in the shape of the loading curve in Figure 4 (i.e., an "S"-shaped loading curve). Based on the slope of the loading curve, the length of the mass transfer zone is estimated to be approximately $21 \mathrm{~cm}$. The total iodine loaded into the mass transfer zone and very short tails is $\sim 5.6 \mathrm{~g}$ on the $126 \mathrm{~g}$ of sorbent. Based on the loading and the same $50 \mathrm{ppb} \mathrm{I}_{2}$ feed gas used in this test, it would require a minimum test duration of $\sim 254$ weeks.

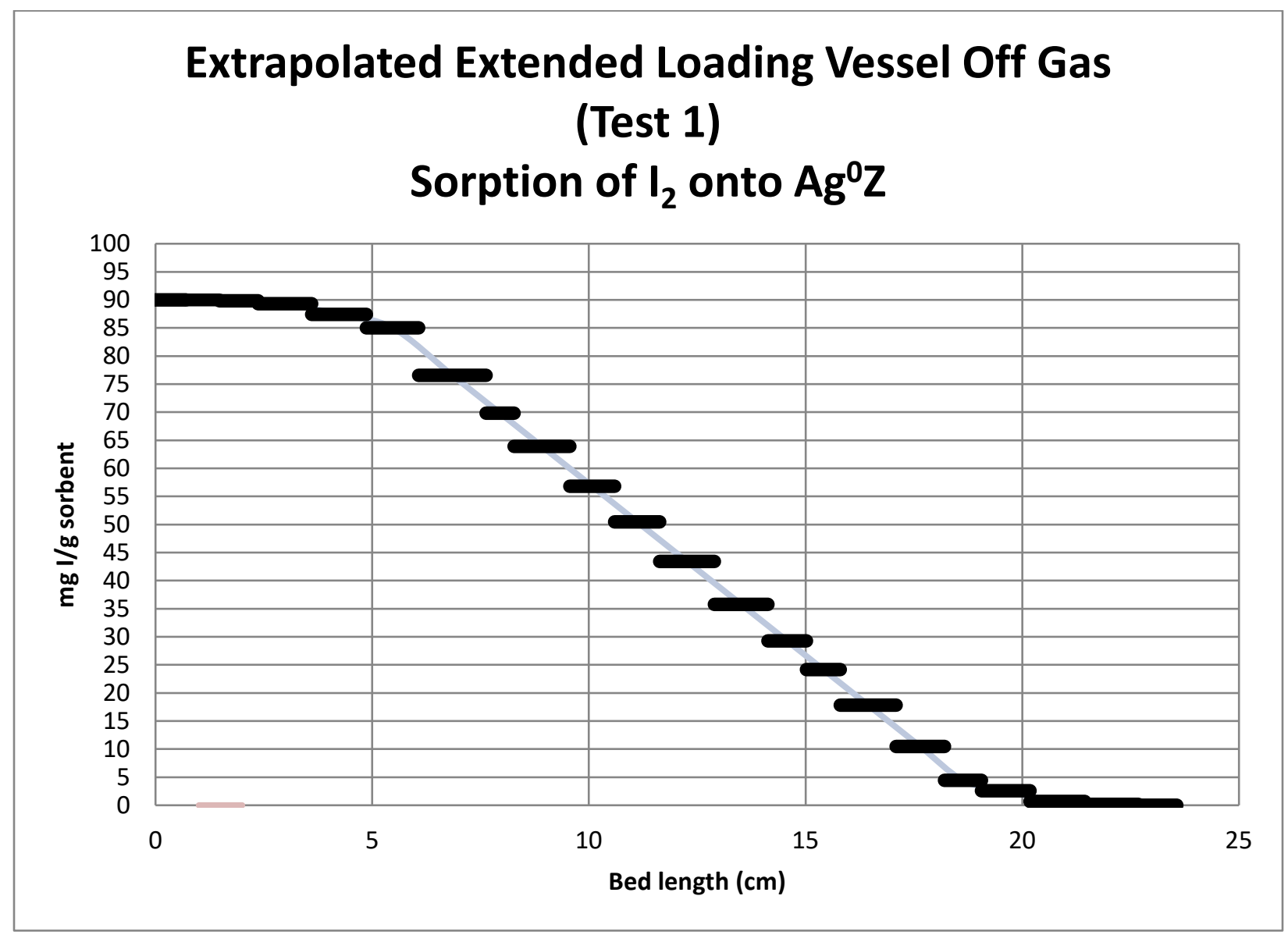

Figure 4. Estimated penetration of $\mathrm{I}_{2}$ into an $\mathrm{Ag}^{0} \mathrm{Z}$ deep bed at breakthrough based on linear regression fit of loading shown in Figure 3 with a saturation loading of $90 \mathrm{mg} \mathrm{I} / \mathrm{g}$ sorbent.

Figure 5 represents a lower estimate of a saturation load representing the $60 \%$ loss of capacity. In this case, a saturation loading is assumed to be $45 \mathrm{mg} \mathrm{I}_{2} / \mathrm{g}$ sorbent. This is also seems reasonable based on the maximum loading achieved ( $\sim 0 \mathrm{mg} \mathrm{I} / \mathrm{g}$ sorbent) prior to the termination of this extended test. The same symmetry is also assumed in the shape of the loading curve in Figure 4 (i.e., an "S"-shaped loading curve). This iodine load scenario assumes the same duration ( 254 weeks with a 50 ppb $\mathrm{I}_{2}$ feed gas) as determined in the previous estimate as represents the same total amount of iodine captured on the bed accounting for the lower saturation loading. Based on the slope of the loading curve, the length of the mass transfer zone is estimated to be approximately $13 \mathrm{~cm}$. The total iodine loaded into the mass transfer zone and very short tails is $\sim 5.6 \mathrm{~g}$ on the $171 \mathrm{~g}$ of sorbent. The minimum bed length required in this case is $\sim 32 \mathrm{~cm}$ as compared to $\sim 24 \mathrm{~cm}$ in the higher saturation loading case shown in Figure 4. 


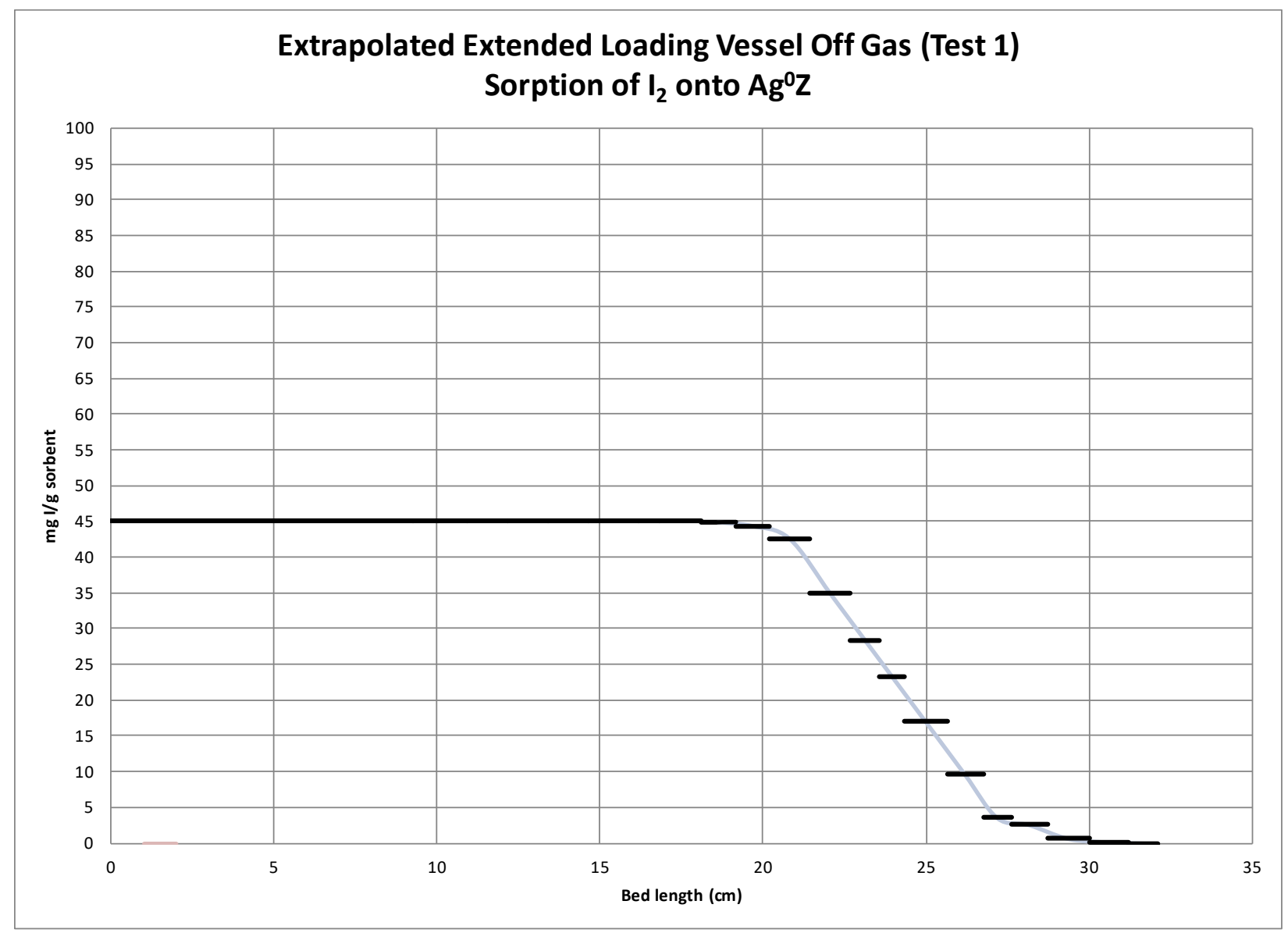

Figure 5. Estimated penetration of $\mathrm{I}_{2}$ into an $\mathrm{Ag}^{0} \mathrm{Z}$ deep bed at breakthrough based on linear regression fit of loading shown in Figure 3 with a saturation loading of $45 \mathrm{mg} \mathrm{I}_{2} / \mathrm{g}$ sorbent.

\subsection{Observations and Conclusions}

This test represents the longest extended VOG test conducted to date by this program. This test ran 38 weeks and achieved iodine loadings of $\sim 40 \mathrm{mg} \mathrm{I} / \mathrm{g}$ sorbent. The iodine mass transfer zone penetrated at least $10.5 \mathrm{~cm}$ into the sorbent beds. Over the first 6-6.5 $\mathrm{cm}$ of the bed, the iodine loading in $\mathrm{mg} \mathrm{I} / \mathrm{gm}$ sorbent appeared to be linear or nearly linear as a function of bed depth. There was no indication of sorbent saturation. The mass balance for iodine closed within $2 \%$, which is well within the expected combined uncertainty.

While this test did not achieve saturation of any portion of the test beds, the data does provide significant information that can be used to extrapolate a potential maximum length of the mass transfer zone under VOG conditions. Under the conditions used in this test, the mass transfer zone could be on the order of $21 \mathrm{~cm}$.

This test also provides the basis for the design of the next series of extended VOG tests. Future tests to examine the validity of the extrapolation to a saturated VOG sorbent bed should be designed to run up to $\sim 4.9$ years, assuming a $50 \mathrm{ppb} \mathrm{I}_{2}$ feed gas and have a bed length greater than $32 \mathrm{~cm}$.

Future efforts on the adsorption of iodine from prototypical VOG streams by silver-based sorbents will attempt to resolve some of the questions raised here, both regarding the mass balance of $\mathrm{CH}_{3} \mathrm{I}$ and the effect of aging on iodine adsorption by $\mathrm{Ag}^{0} \mathrm{Z}$ from a dilute gas stream. Additionally, the adsorption of different iodine species, such as $\mathrm{C}_{12} \mathrm{H}_{25} \mathrm{I}$, will be studied. Other variables that merit examination are the 
gas velocity of the test and the dependence of the observed results on the inlet iodine concentration. An assessment of the residual iodine capacity of the sorbent media following the 8-month online time using media from the final bed segments should also be completed. Finally, longer duration testing or modified test methods should be considered in an effort to determine the mass transfer zone and DF associated with iodine adsorption by $\mathrm{Ag}^{0} \mathrm{Z}$ under prototypical vessel off-gas conditions.

\section{REFERENCES}

Anderson, K. K., S. H. Bruffey, D. L. Lee, R. T. Jubin, and J. F. Walker. 2012. Iodine Loading of Partially Reduced Silver Mordenite. FCRD-SWF-2013-000079, US Department of Energy Separations and Waste Forms Campaign, December 28.

Bruffey, S. H., R. T. Jubin, D. M. Strachan, B. B. Spencer, and B. J. Riley. 2015a. Literature Survey to Identify Potentially Problematic Volatile Iodine-bearing Species Present in Off-gas Streams. ORNL/SPR-2015/290, UT-Battelle, LLC, Oak Ridge National Laboratory, June.

Bruffey, S. H., K. K. Patton, and R. T. Jubin. 2015b. Complete Iodine Loading of NO Aged Ag0functionalized Aerogel. ORNL/LTR-2015/258, UT-Battelle, LLC, Oak Ridge National Laboratory, May.

Bruffey, S. H., R. T. Jubin, and J. A. Jordan. 2016. "Capture of Elemental and Organic Iodine from Dilute Gas Streams by Silver-exchanged Mordenite,” Procedia Chemistry, in press.

Jubin, R. T. 2011. Report of the FY11 Activities of the Off-Gas Sigma Team. FCR\&D-SWF-2011-000306, US Department of Energy Separations and Waste Forms Campaign, September.

Jubin, R. T., N. R. Soelberg, D. M. Strachan, and G. Ilas. 2012. Fuel Age Impacts on Gaseous Fission Product Capture During Separations. Report No. FCRD-SWF-2012-000089, UT-Battelle, LLC, Oak Ridge National Laboratory.

Jubin, R. T., D. M. Strachan, N. R. Soelberg, and G. Ilas. 2013. Iodine Pathways and Off-Gas Stream Characteristics for Aqueous Reprocessing Plants-A Literature Survey and Assessment. Report No. FCRD-SWF-2013-000308, UT-Battelle, LLC, Oak Ridge National Laboratory.

Jubin, R. T., S. H., Bruffey, and B. B. Spencer. 2015. "Performance of Silver-exchanged Mordenite for Iodine Capture under Vessel Off-gas Conditions,” Proceedings of Global 2015, September.

Jubin, R. T., J. A. Jordan, and S. H. Bruffey. 2017. Performance of Silver-Exchanged Mordenite and Silver-Functionalized Silica-Aerogel Under Vessel Off-gas Conditions. Report No. NTRD-MRWFD2017-000034, UT-Battelle, LLC, Oak Ridge National Laboratory.

Matyas, J., N. Canfield, S. Sulaiman, and M. Zumhoff. 2016. "Silica-based Waste Form for Immobilization of Iodine from Reprocessing Off-gas Streams,” J. Nucl. Materials, vol. 476, 255-261, August. 